\title{
On the possible use of Mongolian branchiopods and copepods to establish reference conditions for ecological quality assessment of lacustrine water bodies in Spain
}

\author{
Miguel Alonso
}

Departament de Biologia Evolutiva, Ecologia i Medi Ambient. Universitat de Barcelona. Avda. Diagonal 643. 08028 Barcelona, Spain.

* Corresponding author: malonso@ub.edu

Received: $12 / 11 / 14 \quad$ Accepted: 10/03/17

\begin{abstract}
On the possible use of Mongolian branchiopods and copepods to establish reference conditions for ecological quality assessment of lacustrine water bodies in Spain

A comparison of assemblages of Branchiopoda and Copepoda living in lakes and wetlands in two very distant territories in the Palaearctic Region, the Iberian Peninsula and Mongolia, is presented. Both territories have significant similarities in the hydromorphological and physicochemical characteristics of their water bodies and in the structure and composition of their fauna of branchiopods and copepods. Some species occur in both areas, others are taxonomically closely related, and others behave as geographic vicariants. Most of these microcrustaceans are used as indicators of ecological quality of standing water bodies in industrialized European countries, where reference sites are frequently difficult to find. Taking into account the undisturbed conditions of Mongolian water bodies, the alternative of using their branchiopods and copepods, after setting the proper, statistically-based equivalence between Mongolian and Iberian species, as references to assess ecological status in Spain is discussed.
\end{abstract}

Key words: Branchiopoda, Copepoda, Spain, Mongolia, lake ecological status assessment, reference conditions.

\section{RESUMEN}

Sobre el posible uso de Branquiópodos y Copépodos de Mongolia en el establecimiento de condiciones de referencia para el análisis de la calidad ecológica de las masas de agua lacustre en España

Se presenta una comparación de grupos de Branchiopoda y Copepoda de lagos y humedales en dos territorios muy distantes de la región paleártica: la península ibérica y Mongolia. Los dos territorios tienen similitudes significativas en las características hidromorfológicas y fisicoquímicas de sus masas de agua, y también en la estructura y composición de su fauna de branquiópodos y copépodos. Algunas especies coinciden, otras son muy próximas taxonómicamente y otras se comportan como vicarias geográficas. Muchos de estos microcrustáceos se utilizan como indicadores de calidad ecológica en las masas de agua léntica de los países europeos industrializados, donde las condiciones de referencia son frecuentemente difíciles de encontrar. Teniendo en cuenta la situación inalterada de las masas de agua de Mongolia, se discute la alternativa de utilizar sus copépodos y branquiópodos, tras el necesario análisis de las equivalencias entre ellos y los de la península ibérica, como referencia para determinar el estado ecológico de los lagos en España.

Palabras clave: Branchiopoda, Copepoda, España, Mongolia, evaluación del estado ecológico en lagos, condiciones de referencia. 


\section{INTRODUCTION}

Maintaining the "good ecological status" of water bodies is the main objective of the Water Framework Directive (WFD) (200/60/CE) in all European countries. This Directive was transposed into Spanish law at the end of 2003. Subsequently, the Instrucción de Planificación Hidrológica (hereafter IPH) (Ministerio de Medio Ambiente y Medio Rural y Marino, 2008) was implemented, with its objective being to establish the technical criteria to systematically and homogeneously develop River Basin Management Plans in Spain. Concerning lakes, the IPH defines the systems and protocols for the ecological status assessment, including the definition and exploitation of the biological control networks, and establishes indicators, indexes and reference conditions. The latter are those presented in water bodies of the same category and type as those intended for assessment under pristine conditions or barely altered by anthropic activities.

Several quality elements are taken into account in the ecological status assessment of lakes: biological (phytoplankton, phytobenthos, macrophytes, benthic invertebrates and fishes), physicochemical and hydromorphological. As this paper is concerned with branchiopods and copepods, it is necessary to refer to the IBCAEL (Índice Biótico de Calidad Ecológica en Lagos) published by the Ministerio de Agricultura, Alimentación y Medio Ambiente of the Spanish Government in 2013, whose application is mandatory in the exploitation of the official networks for lake ecological status assessment in compliance with the WFD. The IBCAEL is an adaptation of the QAELS (Qualitat de l'Aigua en Ecosistemes Lenitics Soms) index for the whole Spanish territory designed to assess the ecological status of shallow water bodies in northeast Spain (Catalonia) (Boix et al., 2005). The IBCAEL is calculated as the combination of two subindexes: ABCO (abundance of benthic branchiopods, copepods, and ostracods) and the RIC (insect and crustacean richness). The organisms included in both the ABCO and RIC are good indicators because they are very sensitive to disturbances and changes in their habitats (Stemberger \& Lazorchak, 1994; Hofmann, 1996; Moreno-Amich et al., 1999; Johansson et al., 2005) and spend their entire life cycles, which are relatively long, in the water. Moreover, because some of these microcrustaceans, mainly cladocerans and ostracods, leave remains in the sediment that have been largely used in palaeolimnological studies (Kattel \& Sirocko, 2011; Horne et al., 2012), they are an appropriate tool for searching for the existing species assemblages prior to the existence of anthropic pressures, that is, reference conditions.

Branchiopods and copepods of continental standing waters are well known in Spain (Alonso, 1996; 1998); however, the information regarding these taxa in Mongolia is scattered and incomplete (Sars, 1903; Brtek et al., 1984; Naganawa \& Zagas, 2002; Flossner et al., 2005; Penkova et al., 2005; Pomazkova \& Sheveleva, 2006; Alonso \& Naganawa, 2008; Sinev et al., 2009; Alonso, 2010; Alonso \& Ventura, 2013). In fact, the most comprehensive inventory for this country is currently being performed by the author of this paper, with some of the taxa mentioned below only partially reported in the abovementioned publications.

Reference conditions in Spain are relatively easy to find in high mountain lakes; however, they are practically absent in lowlands due to the ancient occupation of the totality of the territory by agricultural activities and human settlements. In particular, the lakes in the steppes, which were the jewel of the Spanish lacustrine heritage in the past and are almost entirely unique in Western Europe, have disappeared or have been significantly altered. In Mongolia, steppes are widespread and host a huge number of lakes in pristine conditions. Although the Mongolian and Iberian steppes are bioclimatically different, their lakes are similar. This and the presence of even the same or vicarious species and similar species assemblages in both distant territories could allow us to use ABCO values obtained from undisturbed Mongolian lakes as reference conditions for the Spanish lakes.

In this paper, Spanish and Mongolian lakes and lagoons and their branchiopod and copepod 
assemblages are compared. The convenience of using the conditions of Mongolian lakes as a reference for Spanish lakes is discussed.

\section{MATERIALS AND METHODS}

Samples were collected during an extensive survey performed throughout the Mongolian territory, considering all of its natural zones (alpine belts, taiga, forest-steppe, steppe, semidesert and desert zones) between 2005 and 2013. In total, 878 lakes were sampled. Abbreviated descriptions of all the lakes and photos can be seen at http://geodata.es/mongolian_lakes. The surveys were conducted in September-October, after the rainy season and before the freezing of the lake surface; during this period, the crustacean communities reach their peak of maturity, and males and gamogenetic females appear in the cladoceran populations. Samples were obtained from representative habitats in each lake (littoral ar-

Table 1. Correspondence between the IPH and IBCAEL typologies of lakes and lagoons in Spain and the typologies defined for Mongolian lakes in this paper. Correspondencia entre las tipologías IPH e IBCAEL de lagos y lagunas en España y la tipología definida para los lagos de Mongolia en este trabajo.

\begin{tabular}{|c|c|c|c|}
\hline $\begin{array}{l}\text { Typology } \\
\text { IPH }\end{array}$ & Description & $\begin{array}{l}\text { Typology } \\
\text { IBCAEL }\end{array}$ & $\begin{array}{c}\text { Typology } \\
\text { MONGOLIA }\end{array}$ \\
\hline 1 & NORTHERN HIGH MOUNTAIN. DEEP. ACIDIC WATERS & \multirow{5}{*}{1} & \multirow{12}{*}{ A } \\
\hline 2 & NORTHERN HIGH MOUNTAIN. DEEP. ALKALINE WATERS & & \\
\hline 3 & NORTHERN HIGH MOUNTAIN. SHALLOW. ACIDIC WATERS & & \\
\hline 4 & NORTHERN HIGH MOUNTAIN. SHALLOW. ALKALINE WATERS & & \\
\hline 5 & NORTHERN HIGH MOUNTAIN. DEEP. ALKALINE WATERS & & \\
\hline 6 & MEDIUM MOUNTAIN. DEEP. ACIDIC WATERS & \multirow{3}{*}{2} & \\
\hline 7 & MEDIUM MOUNTAIN. DEEP. ALKALINE WATERS & & \\
\hline 8 & MEDIUM MOUNTAIN.SHALLOW. ALKALINE WATERS & & \\
\hline 9 & SOUTHERN HIGH MOUNTAIN & 1 & \\
\hline 10 & KARSTIC, CALCAREOUS, PERMANENT, HYPOGENIC & \multirow{3}{*}{2} & \\
\hline 11 & KARSTIC, CALCAREOUS, PERMANENT, UPWELLING & & \\
\hline 12 & KARSTIC, CALCAREOUS, PERMANENT, TRAVERTINIC & & \\
\hline 13 & KARSTIC, CALCAREOUS, TEMPORARY & 7 & B \\
\hline 14 & KARSTIC, EVAPORITES, HYPOGENIC OR MIXT, LARGE & \multirow{2}{*}{3} & A \\
\hline 15 & KARSTIC, EVAPORITES, HYPOGENIC OR MIXT, SMALL & & \multirow{2}{*}{ B } \\
\hline 16 & INTERIOR IN SEDIMENTATION BASIN (ISB), LOW MINERALIZATION,PERMANENT & 4 & \\
\hline 17 & ISB, LOW MINERALIZATION, TEMPORARY & 7 & B-D \\
\hline 18 & ISB, MEDIUM MINERALIZATION, PERMANENT & 4 & $\mathrm{C}$ \\
\hline 19 & ISB, MEDIUM MINERALIZATION, TEMPORARY & 8 & C-D \\
\hline 20 & ISB, HIGH OR VERY HIGH MINERALIZATION, PERMANENT & 5 & $\mathrm{C}$ \\
\hline 21 & ISB, HIGH OR VERY HIGH MINERALIZATION, TEMPORARY & 8 & C-D \\
\hline 22 & ISB, HYPERSALINE, PERMANENT & 6 & \multirow{2}{*}{$\mathrm{E}$} \\
\hline 23 & ISB, HYPERSALINE, TEMPORARY & 9 & \\
\hline 24 & ISB, FLUVIAL ORIGIN, FLOOD PLAIN, LOW OR MEDIUM MINERALIZATION & \multirow{4}{*}{3} & A-B \\
\hline 25 & ISB, FLUVIAL ORIGIN, FLOODPLAIN, HIGH OR VERY HIGH MINERALIZATION & & $\mathrm{C}$ \\
\hline 26 & ISB, FLUVIAL ORIGIN, FLOODPLAIN, ABANDONED MEANDER & & \multirow{2}{*}{ B } \\
\hline 27 & ISB, ASSOCIATED TO ALKALINE PEATS & & \\
\hline 28 & COASTAL LAGOONS WITHOUT MARINE INFLUENCE & 5 & \\
\hline 29 & COASTAL AMONG DUNES, PERMANENT & 3 & \\
\hline 30 & COASTAL AMONG DUNES, TEMPORARY & 7 & \\
\hline
\end{tabular}


eas, open water, among vegetation) using two handheld nets with mesh sizes of $100 \mu \mathrm{m}$ for cladocerans and copepods and $1 \mathrm{~mm}$ for large branchiopods. Specimens were preserved in $4 \%$ formaldehyde. In the laboratory, most taxa were identified to species.

\section{RESULTS}

\section{Types of lakes in Mongolia}

Five types of lakes can be defined in Mongolia according the following descriptors: morphometry, hydroperiod, mineralization, and inorganic turbidity. This approach is similar to that adopted to classify lakes and lagoons in Spain by Alonso (1998). A brief description of the five types is given below.

- Type A. Large permanent freshwater lakes. In this type of lake, the maximum depth exceeds that which might be colonized by submerged aquatic vegetation, so lake metabolism is controlled by the plankton (trophic status). The specific electrical conductance is below $4000 \mu \mathrm{S} / \mathrm{cm}$. The biota is freshwater stenohaline. Fish are present.

- Type B. Smaller permanent or semipermanent freshwater lakes. In these lakes, aquatic submerged vegetation can colonize almost all of the lake bottom and therefore controls lake metabolism. Water turbidity is not due to inorganic suspended particles. Specific electrical conductance is below $4000 \mu \mathrm{S} / \mathrm{cm}$. The biota is freshwater stenohaline. Fish are present in lakes deeper than $4 \mathrm{~m}$ (ice cover can exceed a thickness of $2 \mathrm{~m}$ in winter).

- Type C. Large lakes and lagoons, either permanent or temporary, with highly mineralized or even saline (not hypersaline) waters. Specific electrical conductance between 4000 and $45000 \mu \mathrm{S} / \mathrm{cm}$. The biota is euryhaline. Fish are present.

- Type D. Shallow lakes and lagoons, either permanent or temporary, with slightly to highly mineralized waters, turbid due to suspended inorganic particles. Specific electrical conductance 4 000-42 $500 \mu \mathrm{S} / \mathrm{cm}$. Turbidity does not allow submerged macrophyte growth. Lake metabolism is heterotrophic. Euryhaline biota. No fish present.

- Type E. Hypersaline lakes. Specific electrical conductance from 45000 to more than $200000 \mu \mathrm{S} / \mathrm{m}$. Stenohaline athalassic saline biota. No fish present.

\section{Branchiopod and copepod assemblages in Mongolia}

The inventory of the Mongolian microcrustaceans on which this paper is based includes eighty-seven branchiopod and forty-nine copepod species.

Branchiopods include 10 Anostraca, 4 Conchostraca, 2 Notostraca, 3 Ctenopoda, 1 Haplopoda and 66 Anomopoda species. With respect to the Iberian fauna (Alonso, 1996; 1998), anostracans, conchostracans and notostracans are the most distinct groups, since only two anostracan species coincide. Of the three ctenopods, two are known in the Iberian Peninsula. Although haplopods do not occur on the Iberian Peninsula, there are 49 anomopod species in common between the two areas.

The copepods include 20 Calanoida, $26 \mathrm{Cy}-$ clopoida and 3 Harpacticoida species. Of the calanoids, which are prone to geographical speciation, only three species occur in both areas, whereas twenty cyclopoid species are shared between Mongolia and the Iberian Peninsula. All harpacticoids found in Mongolia also live in the Iberian Peninsula.

\section{DISCUSSION}

The use of Mongolian lakes as reference conditions for the $\mathrm{ABCO}$ subindex relies on two assumptions: (1) Spanish and Mongolian lakes are typologically equivalent, and (2) microcrustacean assemblages in lakes of the same type resemble one another when undisturbed. 
On the possible use of Mongolian branchiopods and copepods...

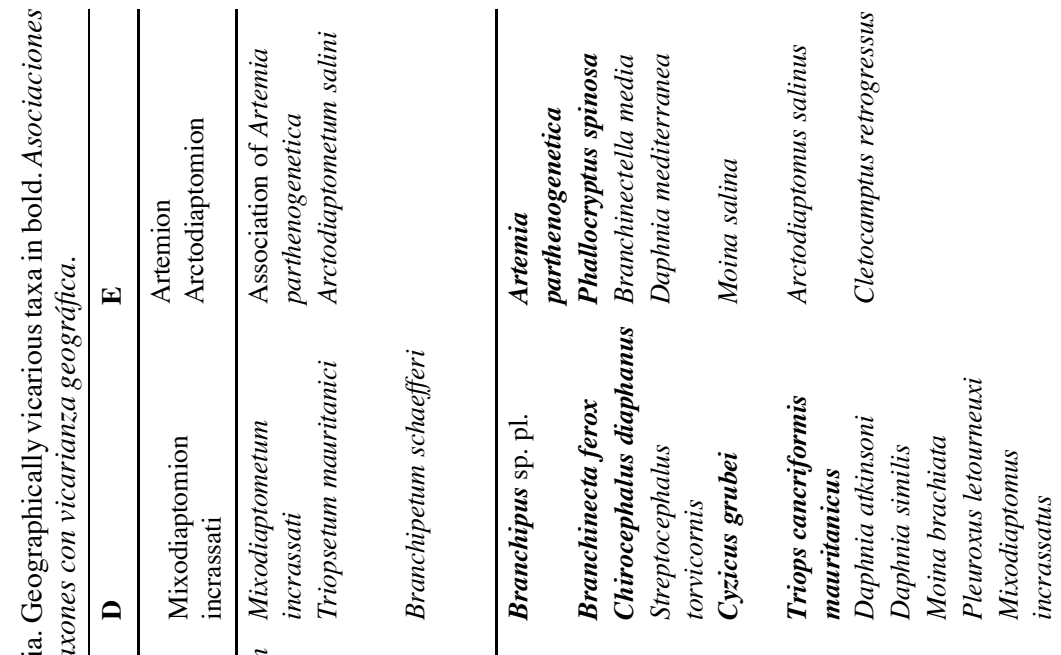

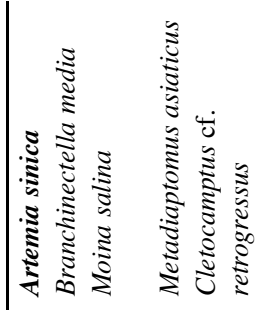

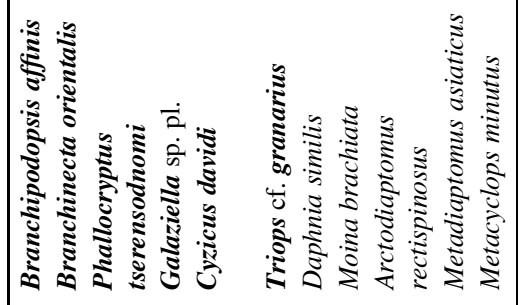

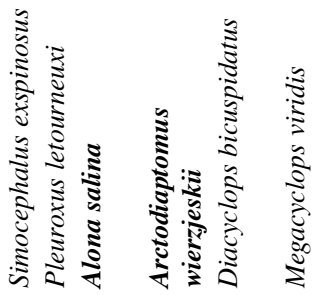

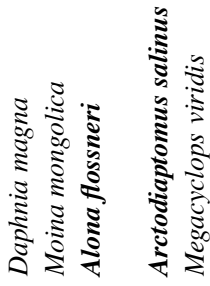

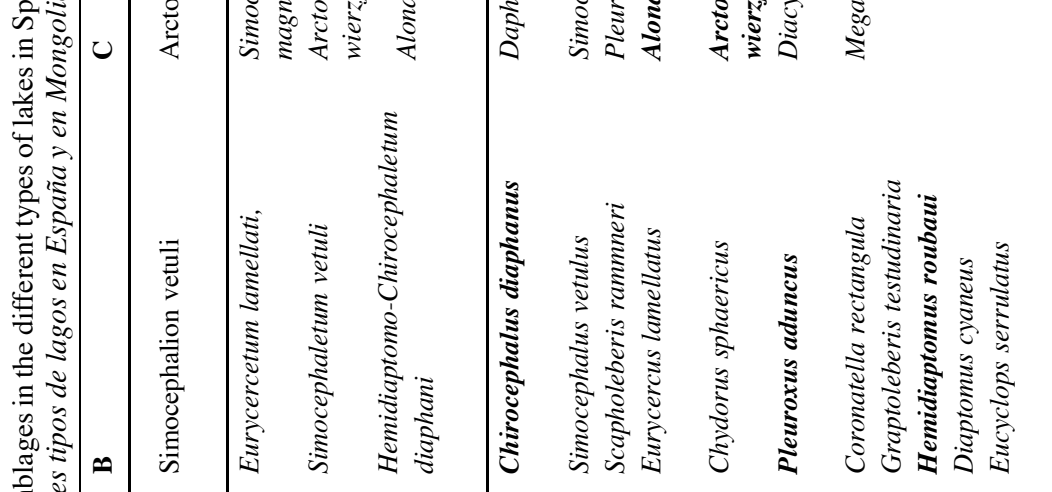

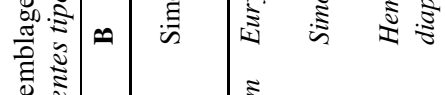

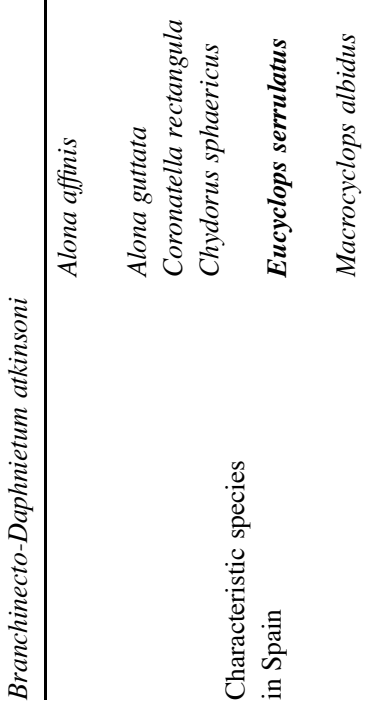

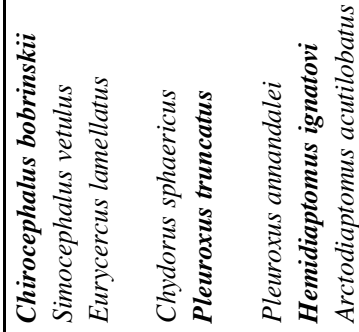

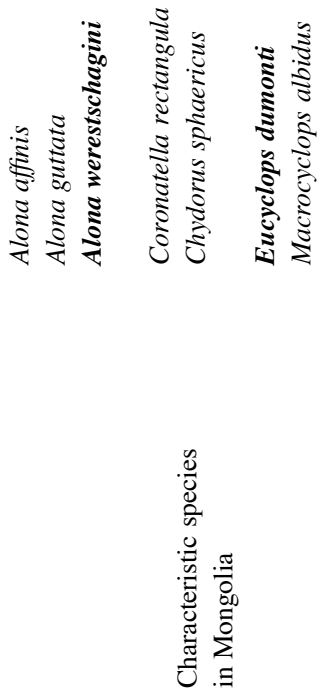


Table 1 shows the relationship between the lake typologies of the IPH and IBCAEL for Spain and those categories defined for Mongolia. The IPH establishes thirty types of lakes in Spain. Lake typology was defined according to the origins of the lake basins (glacial, karstic, fluvial, coastal), altitude, mineralization and type of hydroperiod. The IPH also considers as a distinguishing feature the location in interior sedimentation basins, which is clearly related to steppe conditions in Spain (Suarez Cardona et. al., 1992).

The IBCAEL typology distinguishes nine types. Except for types 6, 8 and 9, which univocally correspond to the IPH types 22,19 and 23 , the rest correspond to groups of IPH types having similar characteristic microcrustacean assemblages with regard to the ABCO subindex.

Excluding IPH types 28, 29 and 30, which are coastal, the rest of the Spanish lake types have a homologous type in Mongolia. Mountain and large karstic lakes in Spain (IPH types 1-12 and 14) correspond mostly to IBCAEL typologies 1,2 , and type "A" in Mongolia. IPH types 13, $15,16,17,24,26$ and 27, which are generally freshwater shallow lagoons, can be assimilated to type " $\mathrm{B}$ " in Mongolia or to type " $\mathrm{D}$ " if the water is turbid because of inorganic particles. IPH types 18-20 and 25, which are characterized by medium or high mineralization, can be assimilated to type "C" in Mongolia or also " $D$ " if they have inorganic turbidity. In addition, the IPH types that are hypersaline can be assimilated to type "E" in Mongolia.

The comparison of the benthic microcrustacean assemblages between the types of lakes and lagoons in Mongolia and in Spain is shown in Table 2. In Alonso (1998), the Spanish microcrustacean communities were characterized by studying the similarity among 470 inventories from a group of Spanish lakes and lagoons representative of all existing types and all regions in the country. The analysis distinguished five taxocenoses, which were designated alliances and associations and helped to finally define the typology of lakes and lagoons in Spain. This typology coincides with that established in Mongolia because it is based on the same principles.
"Characteristic species" in Table 2 indicates the most frequent taxa in each taxocenosis so that the absence of one taxon in one of the assemblages does not necessarily imply that it is absolutely absent in the country to which the assemblage in question applies.

For type "A", most taxa are coincident. For the other types, the taxa that could be used in Mongolia to establish reference conditions are mainly geographically vicarious, coinciding in most cases at the genus level. Some cases are interesting, such as Arctodiaptomus salinus, which has been found in Spain in El Tobar (Miracle et al., 1993) and Banyoles karstic lakes (Miracle, 1976) but also in most hypersaline endorheic lakes (Alonso, 1990); such ambivalence has never been investigated, and there are likely two different species under this specific name. In Mongolia, A. salinus never appears in hypersaline waters, only in highly mineralized waters, being Metadiaptomus asiaticus which characteristically inhabit hypersaline waters..

According to the observations presented here, the use of Mongolian lakes as reference conditions for the IBCAEL index in Spain, mainly for steppe lakes, seems to be realistic. The next step should include the necessary statistical analysis to assign to each taxon the sensibility value which, as was done in Spain, is based on an analysis of the fidelity of the different taxa to each determined lake typology.

\section{ACKNOWLEDGEMENTS}

This study has been supported by the Program for Biodiversity Conservation of ENDESA (Empresa Nacional de Electricidad S.A.).

\section{REFERENCES}

ALONSO, M. 1990. Anostraca, Cladocera and Copepoda of Spanish saline lakes. Hydrobiologia, 197: 221-231. DOI:10.1007/BF00026952

ALONSO, M. 1996. Crustacea Branchiopoda. In M. Ramos (ed): Fauna Ibérica. Museo Nacional de Ciencias Naturales, CSIC, Madrid, 7: 1-486. 
ALONSO, M. 1998. Las lagunas de la España peninsular. Limnetica, 15: 1-176.

ALONSO, M. 2010. Branchiopoda and Copepoda (Crustacea) in Mongolian Saline Lakes. Mongolian Journal of Biological Sciences, 8: 9-16. http: //dx.doi.org/10.22353/mjbs.2010.08.02

ALONSO, M. \& H. NAGANAWA, H. 2008. A new fairy shrimp Galaziella murae (Branchiopoda: Anostraca) from Mongolia. Journal of Biological Research-Thessaloniki, 10: 119-128.

ALONSO, M \& M. VENTURA. 2013. A new fairy shrimp Phallocryptus tserensodnomi (Branchiopoda: Anostraca) from Mongolia. Zootaxa, 3670(3): 349-361. http://dx.doi.org/10.11646/zootaxa.3670. 3.5

BOIX, D., S. GASCON, J. SALA, M. MARTINOY, J. GIFREb \& X. D. QUINTANA. 2005. A new index of water quality assessment in Mediterranean wetlands based on crustacean and insect assemblages: the case of Catalunya (NE Iberian peninsula). Aquatic Conservation: Marine and Freshwater Ecosystems, 15: 635-651. DOI: 10.1002/aqc. 750

BRTEK, J., L. FORRÓ \& J.E. PONYI. 1984. Contributions to the knowledge of the Branchiopoda (Crustacea) fauna of Mongolia. Annales HistoricoNaturales Musei Nationalis Hungarici, 76: 91-99.

EUROPEAN PARLIAMENT \& COUNCIL. 2000. Directive 2000/60/EC of the European Parliament and of the Council of 23 October 2000 establishing a framework for Community action in the field of water policy. OJL, 327: 1-73.

FLOSSNER, D., W. HORN \& M. PAUL. 2005. Notes on the Cladoceran and Copepod Fauna of the Uvs Nuur Basin (Norwest Mongolia). Internat. Revue ges. Hydrobiol., 90: 580-595. DOI: 10.1002/iroh. 200410782

HOFMANN, W. 1996. Empirical relationships between cladoceran fauna and trophic state in thirteen northern German lakes: analysis of surficial sediments. Hydrobiologia, 318: 195-201. doi:10. 1007/BF00016680

HORNE, D., J. HOLMES, J. RODRIGUEZ-LÁZARO \& F. VIEHBERG (eds.) 2012. Ostracoda as Proxies for Quaternary Climate Change. Elsevier.

JOHANSSON, L. S., S.L. AMSINK, R. BJERRING \& E. JEPPESEN. 2005. Mid-to-late-Holocene land-use change and lake development at Dallund Sø, Denmark: trophic structure inferred from cladoceran subfossils. The Holocene, 15: 1143-1151. https://doi.org/10.1191/0959683605hl886rp
KATTEL, G. \& F. SIROCKO. 2011. Palaeocladocerans as indicators of environmental, cultural and archaeological developments in Eifel maar lakes region (West Germany) during the Lateglacial and Holocene Periods. Hydrobiologia. DOI:10. 1007/10750-011-0872-4

MINISTERIO DE AGRICULTURA, ALIMENTACIÓN Y MEDIO AMBIENTE. 2013. Protocolo para el cálculo del índice IBCAEL de invertebrados en lagos. Secretaría General Técnica. Centro de Publcaciones. 1: 13.

MINISTERIO DE MEDIO AMBIENTE Y MEDIO RURAL Y MARINO. 2008. Orden ARM/2656/ 2008, de 10 de septiembre, por la que se aprueba la instrucción de planificación hidrológica. Boletín Oficial del Estado 229.

MIRACLE, M.R. 1976. distribución en el espacio y en el tiempo de las especies de zooplancton del lago de Banyoles. Monografías del Instituto $\mathrm{Na}$ cional para la Conservación de la Naturaleza, 53: 1-270.

MIRACLE, M.R., J. ARMENGOL \& M.J. DASÍ. 1993. Extreme meromixis determines strong differential planktonic vertical distribution. Verh. Internat. Verein. Limnol., 25: 705-710.

MORENO-AMICH, R., X.D. QUINTANA, L. SUÑER, R. TROBAJO \& S. GASCÓN. 1999. Dinámica del heleoplancton en relación a las fluctuaciones hidrológicas en "Aiguamolls de l'Empordà” (NE de la Península Ibérica). Propuesta de un método sencillo de monitorización basado en la abundancia de grupos taxonómicos. Limnetica, 16: 17-31.

NAGANAWA, H. \& B. ZAGAS. 2002. General aspects of the large branchiopod crustacean fauna of Mongolia. Limnology, 3: 181-188. DOI: https://doi. org/10.1007/s102010200022

PENKOVA, O.G., H.G. SHEVELEVA, A. DULMAA, N.V. MAKARKINA \& I.F. KRIVENKOVA. 2005. On ecology of rotifers and lower crustaceans in salt and brackish lakes of Central Asia. Ecosystems of Mongolia and frontier areas of adjacent countries: natural resources, biodiversity and ecological prospects. Proceedings of International Conference. September 2005. Ulaanbaatar, Mongolia.

POMAZCOVA, G.I., \& N.G. SHEVELEVA, 2006. Zooplankton of Lake Hövsgöl. In: The Geology, Biodiversity and Ecology of Lake Hövsgöl (Mongolia). Goulden, C.E. et al. (eds): 179-200. Backhuys Publishers, Leiden, The Netherlands. 
SARS, G.O. 1903. On the crustacean fauna of Central Asia. Part II. Cladocera. Ann. Mus. Zool. Acad. Imp. Sci. St. Petersbourg, 8: 167-194.

SINEV, A.Y, M. ALONSO \& G. SHEVELEVA. 2009. New species of Alona from South-East Russia and Mongolia related to Alona salina Alonso, 1996 (Cladocera: Anomopoda: Chydoridae). Zootaxa, 2326: 1-23.

STEMBERGER, R.S \& J.M. LAZORCHAK. 1994. Zooplankton assemblage responses to disturbance gradients. Canadian Journal of Fisheries and Aquatic Sciences, 51: 2435-2447. https://doi.org/10.11 39/f94-243

SUÁREZ CARDONA, F., H. SAINZ OLLERO, T. SANTOS MARTÍNEZ, F. GONZÁLEZ BERNÁLDEZ. 1992. Las estepas ibéricas. Ministerio de obras públicas y Transportes. Unidades Temáticas Ambietales. Secretaría de Estado para las Políticas del Agua y el Medio Ambiente.

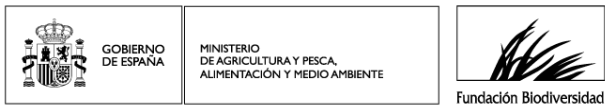

